\title{
Simultaneous measurements of the rates of production of acetic, propionic and butyric acids in the rumen of sheep on different diets and the correlation between production rates and concentrations of these acids in the rumen
}

\author{
By R. A. LENG AND D. J. BRETT \\ Department of Biochemistry and Nutrition, School of Rural Science, \\ University of New England, Armidale, NSW, Australia \\ (Received I 8 October 1965-Accepted 21 March 1966)
}

\begin{abstract}
I. A technique using a constant infusion of $\left[\mathrm{U}-{ }^{14} \mathrm{C}\right]$ acetate, $\left[\mathrm{U}-{ }^{14} \mathrm{C}\right]$ propionate and $[2-3-\mathrm{T}]-$ butyrate has been developed to measure simultaneously the production rates of acetic, propionic and butyric acids in the rumen of sheep. 2. Infusions of ${ }^{14} \mathrm{C}$-labelled acids suggested that interconversions of acetic acid or butyric acid with propionic acid and vice versa were small in extent, but the conversion of acetic acid into butyric acid accounted for between 40 and $50 \%$ of the butyric acid produced. The conversion of butyric acid into acetic acid accounted for $6-13 \%$ of the acetic acid produced in the rumen. 3 . The production rates and the concentrations of individual acids in the rumen were simply related. 4 . The difference between measured production rate and the rates of conversion of one acid into the other two acids for acctic, propionic and butyric acids, were $85-9 \mathrm{r} \%, 9 \mathrm{r}-100 \%$ and $53-73 \%$ of the measured production rates respectively.
\end{abstract}

In a recent report from this laboratory a technique was described which used an intraruminal infusion of ${ }^{14} \mathrm{C}$-labelled acetic, propionic or butyric acid for the measurement of production rates of these compounds in the rumen of sheep (Leng \& Leonard, $1965 a$ ). The technique permits the measurement of the rate of production of a single acid at one time, and in the investigation now reported the technique has been extended so that the production rates of all three acids can be measured simultaneously.

In the past, because of the technical difficulties associated with the accurate measurement of volatile fatty acid (VFA) production rates, only qualitative information has been obtained on the concentration of the total and individual VFA in the rumen of sheep given various diets. It is not known, however, if the concentrations of VFA in the rumen of sheep are simply related to their rates of production. The relationship between concentration and production of VFA in the rumen of sheep on widely different rations has been examined by the isotope dilution method developed in these investigations.

\section{EXPERIMENTAL}

\section{Animals and feeding regime}

Twelve Merino sheep were used. All were provided with a rumen cannula and were housed singly in pens. Groups of three animals were placed on one of the rations: ration $\mathrm{A}, 800 \mathrm{~g}$ lucerne chaff; ration $\mathrm{B}, 400 \mathrm{~g}$ maize plus $200 \mathrm{~g}$ lucerne chaff; ration $\mathrm{C}$, $300 \mathrm{~g}$ lucerne chaff plus $300 \mathrm{~g}$ maize; ration $\mathrm{D}, 45^{\circ} \mathrm{g}$ wheaten straw chaff plus $5^{\circ} \mathrm{g}$ lucerne. 
Sheep were given their ration in twelve equal amounts at hourly intervals between $08 \mathrm{~h}$ and $\mathrm{i} 9 \mathrm{~h}$ for 5 days. Infusions of labelled VFA into the rumen were made on the last day of each 5 -day period. Between these periods the animals were given the total ration once daily (Leng \& Leonard, I965a). All animals were accustomed to the experimental ration for at least $\mathrm{I} 2$ weeks before an infusion was made.

\section{Experimental procedure}

Intraruminal infusions were made by the technique described by Leng \& Leonard $\left(1_{9} 6_{5} a\right)$. In the initial experiments only one labelled acid was used, but because more information was required on interconversion of $\mathrm{VFA}$ in the rumen, $\left[\mathrm{U}-{ }^{14} \mathrm{C}\right]$ acetate or $\left[\mathrm{U}-{ }^{14} \mathrm{C}\right]$ propionate or $\left[\mathrm{I}-2^{14} \mathrm{C}\right]$ butyrate was infused. Measurements of the production rates of the three acids were made by means of a mixed infusate of $\left[\mathrm{U}-{ }^{14} \mathrm{C}\right]$ acetate, $\left[\mathrm{U}-{ }^{14} \mathrm{C}\right]$ propionate and $[2-3-\mathrm{T}]$ butyrate.

All animals were offered food at hourly intervals before and during infusions, which were always commenced when the concentrations of VFA were apparently constant (Leng \& Leonard, $1965 a$ ). Sheep given lucerne chaff consumed their hourly feed in I 5-20 min, but sheep receiving the maize and wheaten chaff rations at times took up to $\mathrm{I} h$ to eat their ration. Infusions were made for $4 \mathrm{~h}$ and five rumen fluid samples were taken at $15 \mathrm{~min}$ intervals from the 180 th to the 240 th min of an infusion.

One sheep from each group was infused on different occasions with [U-14 C]acetate or $\left[\mathrm{U}-{ }^{14} \mathrm{C}\right]$ propionate or $\left[\mathrm{U}-{ }^{14} \mathrm{C}\right]$ butyrate in order to determine production and interconversion rates. All sheep were used when $\left[\mathrm{U}-{ }^{14} \mathrm{C}\right]$ acetate, $\left[\mathrm{U}-{ }^{14} \mathrm{C}\right]$ propionate and [2-3-T] butyrate were infused at one time in order to determine their production rates simultaneously.

\section{Chemical methods}

Methods for the isolation, assay of specific activity and estimation of individual VFA in the rumen fluid have been described (Leng \& Leonard, 1965a). All five rumen samples taken during an infusion were analysed. Radioactivity of the isolated acid was determined in a Nuclear Chicago Scintillation System 725 (Nuclear Chicago Corp., Illinois, USA) and the channels-ratio method for dual isotopes was used to correct for quenching (Hendler, I964). In experiments in which the isolated butyric acid contained a large number of tritium counts and a small number of carbon i 4 counts the vials were always counted twice, the second time after adding a known amount of $\left[{ }^{14} \mathrm{C}\right]$ hexadecane. This was found necessary in order to determine the channels ratio (that is, ' $\mathrm{R}$ ') accurately. Channels ratio counting is essentially differential counting with the total counting window split into two windows for determining quenching correction. ' $R$ ', which is the ratio of counts in one window to that in the other, allows an accurate estimate of efficiency of counting (Hendler, I964).

Production rate and the rate of interconversion of VFA were calculated as previously described by Leng \& Leonard (1965a). 


\section{Measurement of rumen fluid volume and $p H$}

The volume of rumen fluid was determined with the ${ }^{51} \mathrm{Cr}$ complex of ethylenediamine tetraacetic acid prepared by the method of Downes \& McDonald (1964); $60 \mu \mathrm{c} \mathrm{of}{ }^{51} \mathrm{Cr}$ ethylenediamine tetraacetic acid in approximately $\mathrm{I} 0 \mathrm{ml} \mathrm{H}_{2} \mathrm{O}$ were introduced into the rumen through the rumen cannula, and samples of rumen fluid were taken at intervals of $60 \mathrm{~min}$ for $360 \mathrm{~min}$. The samples were centrifuged at $2000 \mathrm{~g}$ for Io $\mathrm{min} ; 5 \mathrm{ml}$ of the clear supernatant fluid were placed in a glass tube and the radioactivity was counted in a well-type, thallium-activated, $\mathrm{NaI}$ crystal scintillation counter.

The logarithms of counts per $\mathrm{ml}$ against time gave a straight-line relationship which was extrapolated to zero time to allow estimates to be made of the dilution of radioactivity at zero time and thus the volume of liquid in the rumen. The $\mathrm{pH}$ of the rumen fluid was measured at hourly intervals over the period of an infusion; samples were obtained without suction and placed in a beaker under paraffin oil.

\section{Radioactive compounds}

Sodium $\left[\mathrm{U}-{ }^{14} \mathrm{C}\right]$ acetate, sodium $\left[\mathrm{I}^{14} \mathrm{C}\right]$ propionate, sodium $\left[\mathrm{I}-{ }^{-14} \mathrm{C}\right]$ butyrate, sodium $\left[2-{ }^{14} \mathrm{C}\right]$ butyrate, sodium $[2-3-\mathrm{T}]$ butyrate and ${ }^{51} \mathrm{Cr}$ were purchased from the Radiochemical Centre, Amersham, England. $\left[2-{ }^{14} \mathrm{C}\right]$ propionate and $\left[3^{-14} \mathrm{C}\right]$ propionate were purchased from N. V. Phillips-Duphar, Amsterdam, Holland.

Uniformly labelled propionate and $\left[1-2-{ }^{14} \mathrm{C}\right]$ butyrate were prepared by mixing the appropriately labelled compounds. The ${ }^{51} \mathrm{Cr}$ complex of ethylenediamine tetraacetic acid was prepared as described by Downes \& McDonald (1964). Examination of the radiochemical compounds by gas-liquid chromatography, as described on p. 542 , showed these to be essentially free from contamination.

\section{RESULTS}

In the investigation presented here the production rate of an acid is defined as the rate at which it enters the pool already present in the rumen, and so the terms 'production rate' and 'entry rate' are synonymous.

Table I. Rumen fluid volume and $p H$ of rumen fluid in sheep receiving four rations

\begin{tabular}{|c|c|c|c|c|c|}
\hline \multirow[b]{2}{*}{ Sheep no. } & \multirow[b]{2}{*}{ Ration * } & \multirow{2}{*}{$\begin{array}{l}\text { Sheep wt } \\
\text { (kg) }\end{array}$} & \multicolumn{2}{|c|}{$\mathrm{pH}$ of rumen fluid $\dagger$} & \multirow{2}{*}{$\begin{array}{l}\text { Rumen } \\
\text { fluid } \\
\text { volume } \\
\text { (l.) }\end{array}$} \\
\hline & & & Mean & Range & \\
\hline 67 & A & $34^{\circ} \circ$ & $6 \cdot 30$ & $6 \cdot 20-6 \cdot 35$ & $3 \cdot 30$ \\
\hline 68 & A & $34 \cdot 2$ & $6 \cdot 17$ & $6 \cdot 10-6 \cdot 35$ & $6 \cdot 25$ \\
\hline 37 & B & $31 \cdot 0$ & $6 \cdot 23$ & $6 \cdot 20-6 \cdot 35$ & 5.01 \\
\hline II 7 & B & $3 I \cdot 0$ & $5 \cdot 95$ & $5 \cdot 60-6 \cdot 05$ & $2 \cdot 86$ \\
\hline I 16 & $\mathrm{C}$ & $30 \cdot 0$ & $6 \cdot 29$ & $6 \cdot 25-6 \cdot 30$ & 3.00 \\
\hline II9 & $\mathrm{C}$ & $30 \cdot 0$ & $6 \cdot 00$ & $5 \cdot 90-6 \cdot I_{5}$ & $3 \cdot 87$ \\
\hline 142 & D & $29 \cdot 6$ & $7 \cdot 00$ & $6.85-7.10$ & $5 \cdot 23$ \\
\hline 96 & $\mathbf{D}$ & 30.0 & $6 \cdot 74$ & $6.65-6.90$ & $4 \cdot 54$ \\
\hline
\end{tabular}

* Details of the rations are given on p. 54I, the sheep were fed at hourly intervals.

$\uparrow \mathrm{pH}$ measurements are the means for five samples obtained over the usual period of an infusion. 


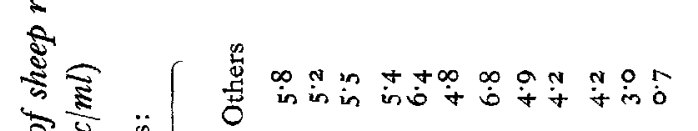

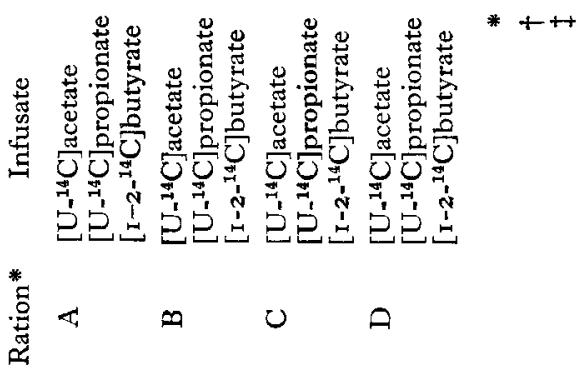

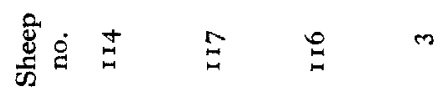




\section{Rumen $p H$ and rumen fluid volume of sheep fed on different rations}

There was considerable variation in the volume of the rumen fluid and the $\mathrm{pH}$ of the fluid between sheep on different rations; $\mathrm{pH}$ varied from $7 \cdot \circ$ on the wheaten straw ration (ration $\mathrm{D}$ ) to 5.95 on the high-maize ration (ration $\mathrm{B}$ ). The fluid volume varied considerably between individual sheep on the same ration and between sheep on different rations. The range of values was from $2 \cdot 9$ to $6 \cdot 3 \mathrm{l}$. (Table $\mathrm{r}$ ).

\section{Concentration and production rates of individual VFA measured from an infusion of one labelled acid}

The concentrations and production rates of individual VFA in the rumen of sheep on the different rations are shown in Table 2 . There was some variation in rumen VFA concentrations in sheep given a high-maize ration (ration $\mathrm{B}$ ), but in sheep given wheaten straw chaff (ration D) or lucerne (ration A) the mean concentrations of VFA were mostly fairly similar in different experiments ('Table 2).

Table 3 . Interconversion of volatile fatty acids in the rumen of sheep receiving four rations*

\begin{tabular}{|c|c|c|c|c|c|c|c|}
\hline $\begin{array}{c}\text { Sheep } \\
\text { no. }\end{array}$ & Ration* & $\begin{array}{c}\% \\
\text { acetic } \\
\text { acid } \\
\text { produced } \\
\text { from } \\
\text { propionic } \\
\text { acid }\end{array}$ & $\begin{array}{c}\% \\
\text { acetic } \\
\text { acid } \\
\text { produced } \\
\text { from } \\
\text { butyric } \\
\text { acid }\end{array}$ & $\begin{array}{l}\% \\
\text { propionic } \\
\text { acid } \\
\text { produced } \\
\text { from } \\
\text { acetic } \\
\text { acid }\end{array}$ & $\begin{array}{c}\% \\
\text { propionic } \\
\text { acid } \\
\text { produced } \\
\text { from } \\
\text { butyric } \\
\text { acid }\end{array}$ & $\begin{array}{c}\% \\
\text { butyric } \\
\text { acid } \\
\text { produced } \\
\text { from } \\
\text { acetic } \\
\text { acid }\end{array}$ & $\begin{array}{c}\% \\
\text { butyric } \\
\text { acid } \\
\text { produced } \\
\text { from } \\
\text { propionic } \\
\text { acid }\end{array}$ \\
\hline 114 & A & 0 & I I $\cdot 2$ & 3.9 & $3 . I$ & $46 \cdot 8$ & 0 \\
\hline 117 & B & 0.2 & $12 \cdot 2$ & $6 \cdot 1$ & $2 \cdot 6$ & $43^{\cdot 6}$ & 0.2 \\
\hline 116 & $\mathrm{C}$ & $1 \cdot 4$ & 13.0 & $4 \cdot 3$ & $2 \cdot 9$ & $47 \cdot 7$ & $2 \cdot 3$ \\
\hline 43 & $\mathrm{D}$ & 0.2 & $6 \cdot 3$ & $2 \cdot 7$ & $2 \cdot 0$ & $40 \cdot 2$ & 0.3 \\
\hline
\end{tabular}

* Details of the rations are given on p. 54I. The sheep were fed at hourly intervals.

Table 4. Ratio of tritium to carbon-14 in rumen butyrate during simultaneous infusion of $\left[\mathrm{I}-2-^{14} \mathrm{C}\right]$ butyrate and $[2-3-\mathrm{T}]$ butyrate into the rumen of sheep receiving four rations*

\begin{tabular}{|c|c|c|c|c|}
\hline \multirow{2}{*}{$\begin{array}{l}\text { Time from } \\
\text { start of } \\
\text { infusion } \\
\text { (min) }\end{array}$} & \multicolumn{4}{|c|}{ Ratio of tritium to carbon- 14 in rumen butyric acid } \\
\hline & $\begin{array}{c}\text { Ration } \\
\text { A }\end{array}$ & $\begin{array}{c}\text { Ration } \\
\text { B }\end{array}$ & $\underset{\mathrm{C}}{\text { Ration }}$ & $\begin{array}{c}\text { Ration } \\
\text { D }\end{array}$ \\
\hline 0 & $3.4 \mathrm{I}$ & $3.4 \mathrm{I}$ & $3.4 I$ & $3.4 \mathrm{I}$ \\
\hline I 80 & $3 \cdot 44$ & $3 \cdot 54$ & $3 \cdot 49$ & $3 \cdot 61$ \\
\hline I95 & $3 \cdot 49$ & 3.44 & 3.50 & $3 \cdot 63$ \\
\hline 210 & $3 \cdot 62$ & $3 \cdot 47$ & 3.50 & 3.58 \\
\hline 225 & $3 \cdot 72$ & 3.49 & $3 \cdot 24$ & $3 \cdot 56$ \\
\hline 240 & $3 \cdot 41$ & 3.50 & $3 \cdot 4 I$ & 3.49 \\
\hline
\end{tabular}

* Details of the rations are given on p. 541. The sheep were fed at hourly intervals.

\section{Percentage interconversion of $V F A$ in the rumen}

The percentage interconversions of VFA in the rumen, determined by comparing the specific activities of individual VFA in the rumen fluid between 180 and $260 \mathrm{~min}$ of an infusion are given in Table 3 . 


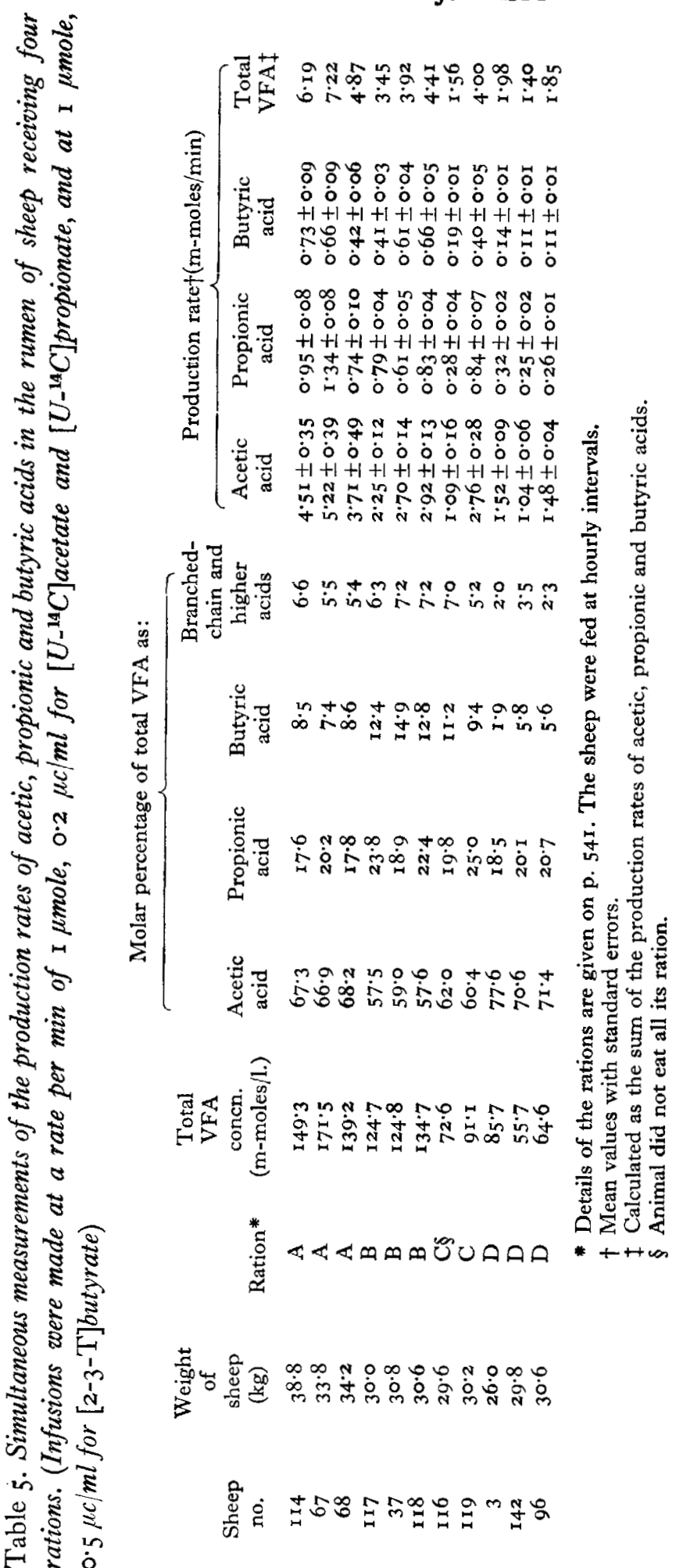




\section{Production rates of butyric acid from infusions of$$
\left[\mathrm{I}-2-{ }^{14} \mathrm{C}\right] \text { butyrate and }[2-3-T] \text { butyrate }
$$

The results given in Table 2 show that rumen VFA concentrations were not always the same between experimental periods in any one sheep; the production rates of acetic, propionic and butyric acids measured at different times are therefore difficult to relate. The values reported in Table 3 suggest that there was negligible interconversion of acetic or butyric acids with propionic acid and vice versa. It has been shown previously that the methyl tritium of [2-T]acetate was labile in rumen fluid (Leng \& Leonard, $\mathrm{I}_{96}{ }_{5} b$ ). When a mixed intraruminal infusion of $\left[\mathrm{r}_{-2}-{ }^{14} \mathrm{C}\right]$ butyrate and $[2-3-T]$ butyrate was made there was, however, no change in the ratio of tritium to carbon $\mathrm{I}_{4}$ in butyrate isolated from rumen fluid over the infusion period (Table 4).

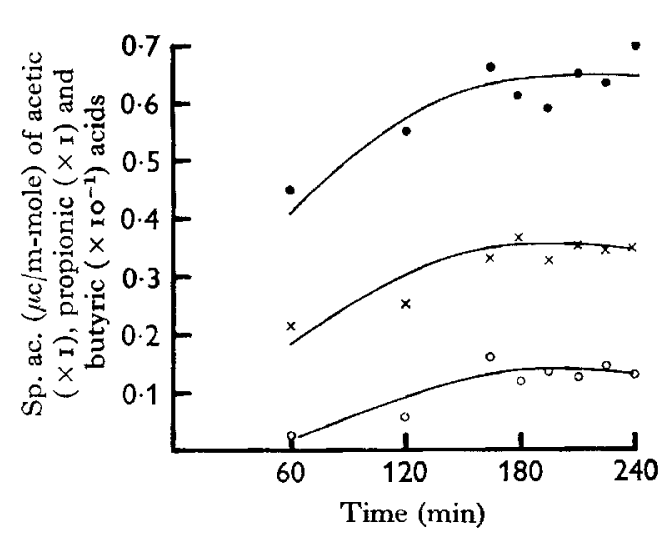

Fig. I

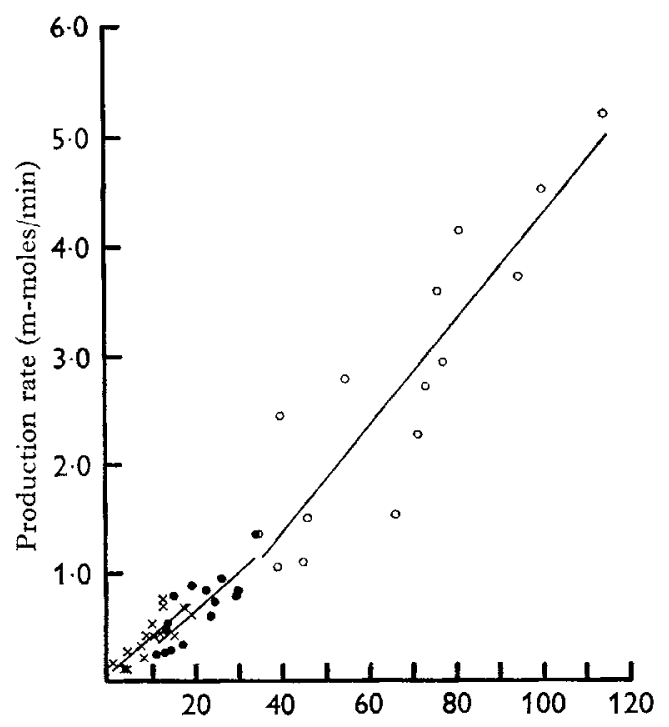

Concentration in rumen fluid (m-moles/1.)

Fig. 2

Fig. I. Specific activities of volatile fatty acids in. the rumen of sheep during simultaneous infusion of $\left[\mathrm{U}-{ }^{14} \mathrm{C}\right]$ acetate, $\left[\mathrm{U}-{ }^{14} \mathrm{C}\right]$ propionate and $[2-3-\mathrm{T}]$ butyrate. The sheep was given a total of $45 \circ \mathrm{g}$ wheaten straw chaff plus $50 \mathrm{~g}$ lucerne. Infusion was at a rate per min of $0 \cdot 2 \mu \mathrm{c}$ for $\left[\mathrm{U}-{ }^{14} \mathrm{C}\right]$ acetate and $\left[\mathrm{U}-{ }^{14} \mathrm{C}\right]$ propionate and $0.5 \mu \mathrm{c}$ for $[2-3-\mathrm{T}]$ butyrate. 0 , acetic acid; $\bullet$, propionic acid; $x$, butyric acid.

Fig. 2. Volatile fatty acid production in relation to concentration in the rumen fluid of sheep. 0 , acetic acid; $\bullet$, propionic acid; $\times$, butyric acid. Regression equations for prediction of production rate from concentration are given on p. 549.

\section{Production rates of acetic, propionic and butyric acids measured simultaneously}

Fig. I shows the changes of specific activities of acetic, propionic and butyric acids during an intraruminal infusion of all three tracers into a sheep given ration $\mathrm{D}$. The variations in specific activities shown in Fig. I were typical of those in most experiments.

The production rate of an acid was estimated by comparing the mean specific activity of an acid between 180 and $24^{\circ} \mathrm{min}$ of an infusion with the rate of infusion 


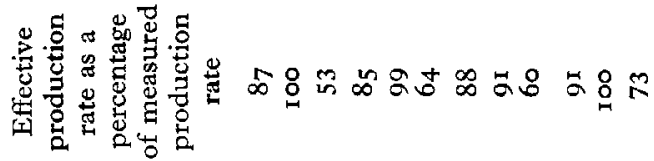

絭

$\stackrel{5}{5}$

$\cdot \frac{\sqrt{4}}{80}$

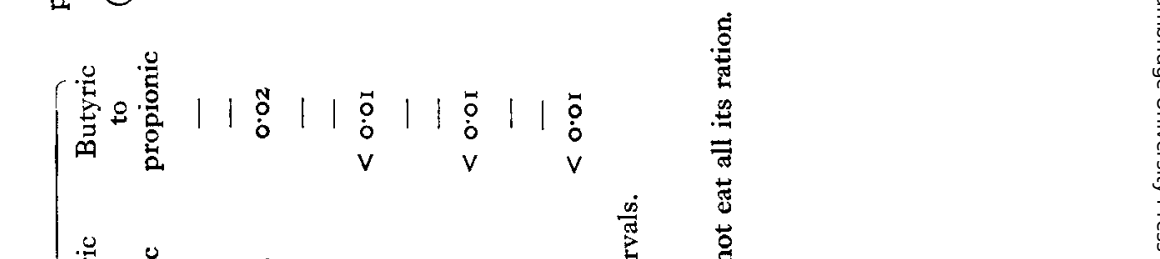

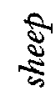

bे

\$

\$ั)

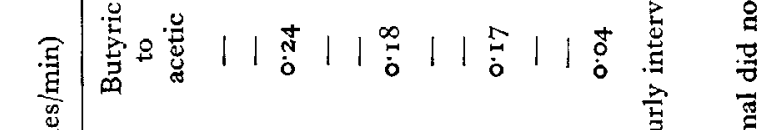

类

若

हुํำ

.

$\sqrt{3}$

胥

$\frac{-\sqrt{5}}{\sqrt[3]{5}}$

คิ

8

.

(ำ



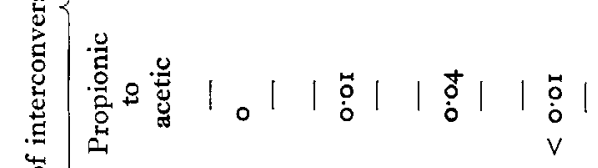

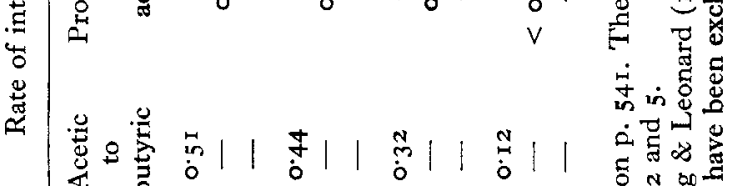

5

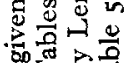

政

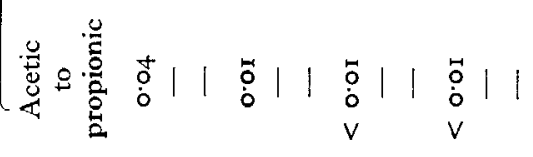

的

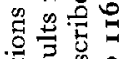

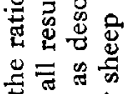

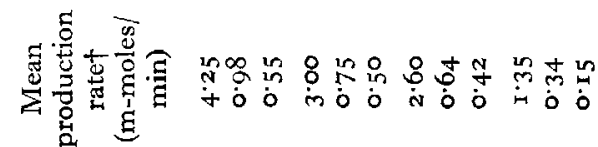

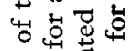

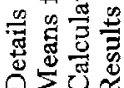

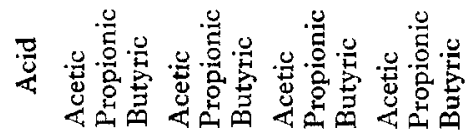

$+t+\infty$

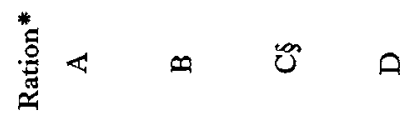


of radioactivity. The production rates of individual VFA estimated simultaneously for sheep on each ration are shown in Table 5. The concentrations of acetic, propionic and butyric acids were related to their production rates (Fig. 2). Regression equations for prediction of production rate of an acid from its concentration (see Fig. 2) are:

$$
\begin{array}{ll}
Y_{\mathrm{ac}}=0.048 X_{\mathrm{ac}}-0.558 & ( \pm 0.007), \\
Y_{\mathrm{pr}}=0.035 X_{\mathrm{pr}}-0.059 & ( \pm 0.006), \\
Y_{\mathrm{bu}}=0.034 X_{\mathrm{bu}}+0.055 & ( \pm 0.006),
\end{array}
$$

where $Y_{\mathrm{ac}}, Y_{\mathrm{pr}}$ and $Y_{\mathrm{bu}}$ are the production rates of acetic, propionic and butyric acids respectively (in m-moles/min), and $X_{\mathrm{ac}}, X_{\mathrm{pr}}$ and $X_{\mathrm{bu}}$ the rumen fluid concentration of acetic, propionic and butyric acids respectively (in m-moles/l.). The residual standard deviations for the regression equations 1,2 and 3 were $0.610,0.178$ and o. I I $\mathrm{m}$-moles/min respectively.

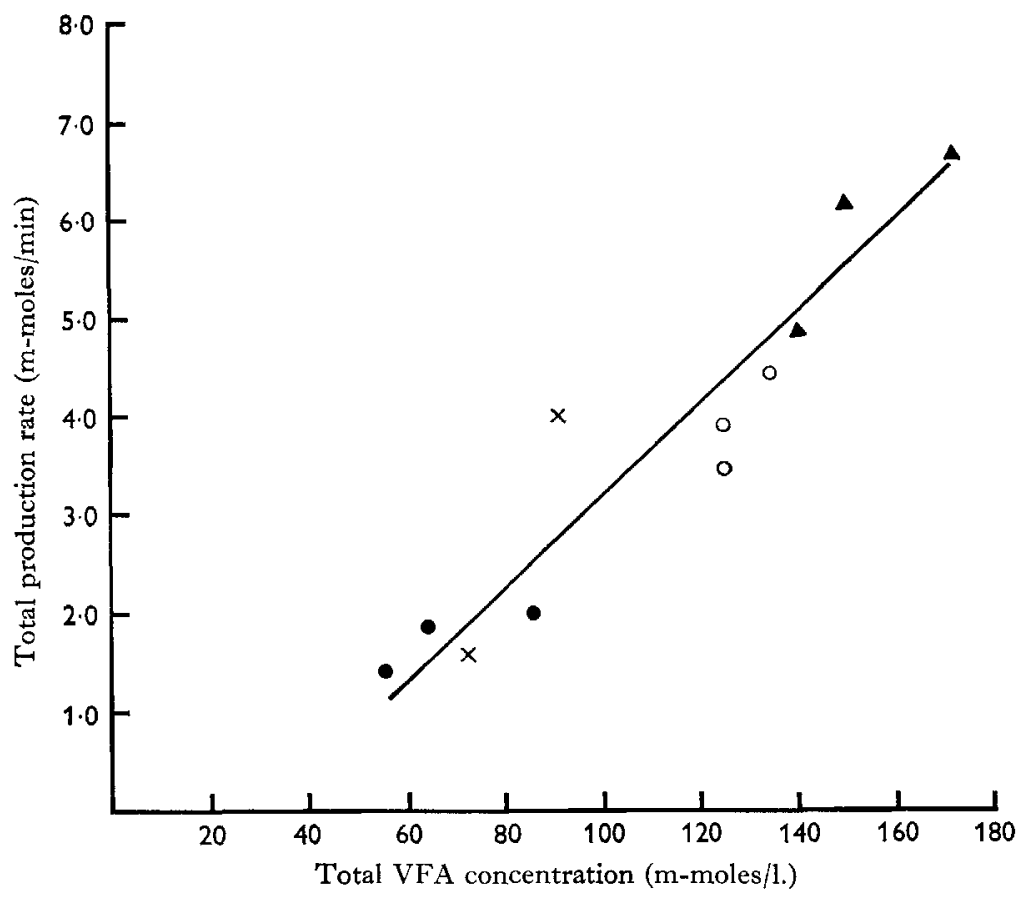

Fig. 3. Total production rates of acetic, propionic and butyric acids (m-moles/min) in relation to the total concentrations of volatile fatty acids in the rumen of sheep. $\Delta$, sheep given $800 \mathrm{~g}$ lucerne; $0,400 \mathrm{~g}$ maize, $200 \mathrm{~g}$ lucerne; $\times$, $300 \mathrm{~g}$ maize, $300 \mathrm{~g}$ lucerne; $\bullet, 450 \mathrm{~g}$ wheaten straw chaff, $50 \mathrm{~g}$ lucerne.

\section{Total VFA production rates}

Since production rates of the acids were measured simultaneously it is possible to obtain a total production rate by summing the three individual production rates. The relationship between total production rate and total VFA concentration is best described by the equation $Y_{t}=0.047 X_{t}-1.514$. The residual standard deviation was $0.683 \mathrm{~m}-\mathrm{moles} / \mathrm{min}$ and the standard error of the regression coefficient was \pm 0.006 (Fig. 3). 


\section{Effective production rates of $V F A$}

The effective production rate of an acid is defined as the difference between the measured production rate and the rate of conversion of that acid into the other two acids (Leng \& Leonard, $1965 a$ ). The effective production rate may be close to the rate at which VFA become available for absorption. Table 6 shows the results for calculated rates of interconversion of VFA. On all rations examined, the effective production rate as a percentage of the measured production rate was between 85 and 91 \% for acetic acid, between 91 and $100 \%$ for propionic acid, and between 53 and $73 \%$ for butyric acid.

\section{DISCUSSION}

The primary aim of this investigation was to attempt to establish a relationship between the concentration of individual VFA and their rates of production in the rumen.

The technique developed for simultaneous measurement of production rates of acetic, propionic and butyric acids has obvious advantages over the earlier method described by Leng \& Leonard ( $\left.196_{5} a\right)$. The measurements of production rates of individual acids were necessarily made at different times in the same sheep and there were often marked variations in VFA concentrations and percentages (Table 2). A technique that enables all three acids to be measured at one time obviously gives more meaningful results and also allows the estimation of the total VFA production rate, that is, the sum of the production rates of acetic, propionic and butyric acids. The technique has many features which make it suitable for use in investigations of the effects of different physiological and nutritional conditions on sheep. The procedure is relatively simple, the techniques and apparatus involved are usually readily available, and it should also be possible to obtain results for large numbers of animals.

In the initial studies with mixed isotopes it was established that [2-3-T]butyrate could be used instead of $\left[1-2-{ }^{14} \mathrm{C}\right]$ butyrate and there was no significant difference between production rates estimated by simultaneous infusion of the two tracers (Table 4 ). The plateau specific activities obtained with the mixed infusate of $\left[\mathrm{U}-{ }^{14} \mathrm{C}\right]-$ acetate, $\left[\mathrm{U}_{-1}{ }^{14} \mathrm{C}\right]$ propionate and $[2-3-\mathrm{T}]$ butyrate in animals given a wheaten straw chaff diet are shown in Fig. I. The results in sheep on other diets were similar in shape and differed only in magnitude.

Previously the measurements of production rates were made with infusion of $\left[\mathrm{I}^{14} \mathrm{C}\right]$-labelled acids and the interconversion percentages were estimated on the assumption that all carbon atoms of the acids reacted similarly (Leng \& Leonard, ${ }_{1}{ }^{6} 6_{5} a$ ). In the studies now presented $\left[\mathrm{U}-{ }^{14} \mathrm{C}\right]$ acetate, [U-14 $\left.\mathrm{C}\right]$ propionate and $\left[\mathrm{I}-\mathbf{2}^{-14} \mathrm{C}\right]-$ butyrate were used, and it soon became apparent that previous assumptions about the interconversion of acetic and butyric acids were invalid and that a much greater proportion of the butyric acid was produced from acetic acid than had been assumed previously. On all rations a total of between 40 and $50 \%$ of the butyric acid was produced from acetic acid (Table 3 ). 
There appears to be a clear general correlation between production rates and concentrations of the individual acids in the rumen (Fig. 2). This is surprising, since estimates of the volume of fluid in the rumen, based on infusions of the ${ }^{51} \mathrm{Cr}$ complex of ethylenediamine tetraacetic acid, showed that in the sheep in these experiments the rumen fluid volume varied between 3 and 61 . There was also a large variation in rumen fluid $\mathrm{pH}$. For instance, in sheep given the wheaten straw chaff the $\mathrm{pH}$ was about 7 , whereas in sheep given high-maize rations the $\mathrm{pH}$ was about 6 .

The concentration of VFA in the rumen must be determined by an equilibrium between the rates of production and of absorption, movement of rumen contents along the intestinal tract, dilution of rumen fluid with saliva and also water movement across the epithelium, and the rate of uptake of VFA by rumen micro-organisms. The concentration of VFA finally attained in the rumen may be due mainly to the balance between the rates of production and of absorption. Absorption of VFA is apparently a passive uptake due to a concentration gradient between rumen fluid and blood (Tsuda, 1956; Dobson, 1961) and may depend upon the amount of rumen epithelium actually in contact with the rumen liquor. It is possible that the amount of tissue in contact with the fluid is not changed appreciably by the differences, found in these experiments, in the volume of materials in the rumen.

The apparent lack of effect of $\mathrm{pH}$ on the relationship observed in these studies is more difficult to attempt to explain. If it is assumed that the rate of absorption of fatty acid is markedly affected by the $\mathrm{pH}$ of the medium then it may be that the fluid immediately surrounding the papilla of the rumen wall has its own micro-environment which is maintained by the movement of ions from the blood, and this allows the uptake of the acids at a constant rate which depends on the concentration of VFA in the rumen. Dobson (1961) suggested that the diffusion of carbon dioxide into the rumen may assist VFA absorption, and Ash \& Dobson ( 1963 ) have recently described certain relationships between carbon dioxide diffusion and VFA absorption; they suggest that carbon dioxide diffuses into the rumen and increases the hydrogen ion concentration of the rumen contents. If there is a localized depression of $\mathrm{pH}$ at the surface of the rumen epithelium then the uptake of VFA may be dependent upon the rate of formation of the free acids at the surface of the papilla.

The uptake of VFA from the rumen will also depend on the blood flow to the rumen, and there is some indication of an increased portal blood flow when the concentrations of VFA in the rumen are raised. Dobson \& Phillipson (1956) reported an increased portal blood flow in anaesthetized sheep when the VFA concentrations in the rumen were increased. Bensadoun \& Reid (1962) showed that portal blood flow increased in sheep after ingestion of food but, although the concentrations of VFA in the rumen and the portal blood flow showed similar trends, correlation coefficients were not significant for the two sheep that were used in those studies (Bensadoun \& Reid, 1962). Portal blood flow has not been measured under a feeding regime in which food has been given at frequent intervals.

Calculations of the extent of interconversion of VFA suggested that the measured production rates for acetic and butyric acids overestimated the amounts of these acids available for absorption. If it is assumed, however, that the percentage interconversion 
of VFA is fairly constant between two acids, then the regression equations in Fig. 2 could be corrected to give values for effective production rates.

The regression equations obtained in these investigations may be useful in interpreting field observations. Further work is required, however, to relate the production of individual organic acids in the rumen to the performance of the animal in the field. Also it is necessary to assess the contribution of VFA to the total energy metabolism of sheep.

We are indebted to the Rural Credits Development Fund, the Australian Wool Board and the University of New England for financial support for this project. We also thank Mr J. L. Corbett and Dr J. P. Langlands for assistance with the statistical analysis.

\section{REFEREN CES}

Ash, R. W. \& Dobson, A. (1963). F. Physiol, Lond. 169, 39.

Bensadoun, A. \& Reid, J. T. (1962). 7. Dairy Sci. 45, 540.

Dobson, A. (196r). In Digestive Physiology and Nutrition of the Ruminant, p. 68. [D. Lewis, editor.] London: Butterworths.

Dobson, A. \& Phillipson, A. T. (1956). Y. Physiol., Land. 133, 76 P.

Downes, A. M. \& McDonald, I. W. (1964). Br. F. Nutr. 18, 153.

Hendler, R. W. (1964). Analyt. Biochem. 7, i ro.

Leng, R. A. \& Leonard, G. J. (1965a). Br.F. Nutr. 19, 469.

Leng, R. A. \& Leonard, G. J. (1965b). Nature, Lond. 207, 760.

Tsuda, T. (1956). Tohoku F. agric. Res, 7, 241. 